\title{
LANGERHANS CELL HISTIOCYTOSIS PRESENTING AS RECURRENT OTALGIA
}

\section{Yousuf Hussain, Antonia Tse, Surya Narayan \\ East Lancashire Hospitals NHS Trust}

East Lancashire Hospitals W/HS NHS Trust

\section{BACKGROUND}

Langerhans cell histiocytosis (LCH) denotes conditions where there is over proliferation of bone marrow-like cells.

- Although macrophages are useful as part of the body's immune system, when pathological proliferation occurs there can be destructive consequences.

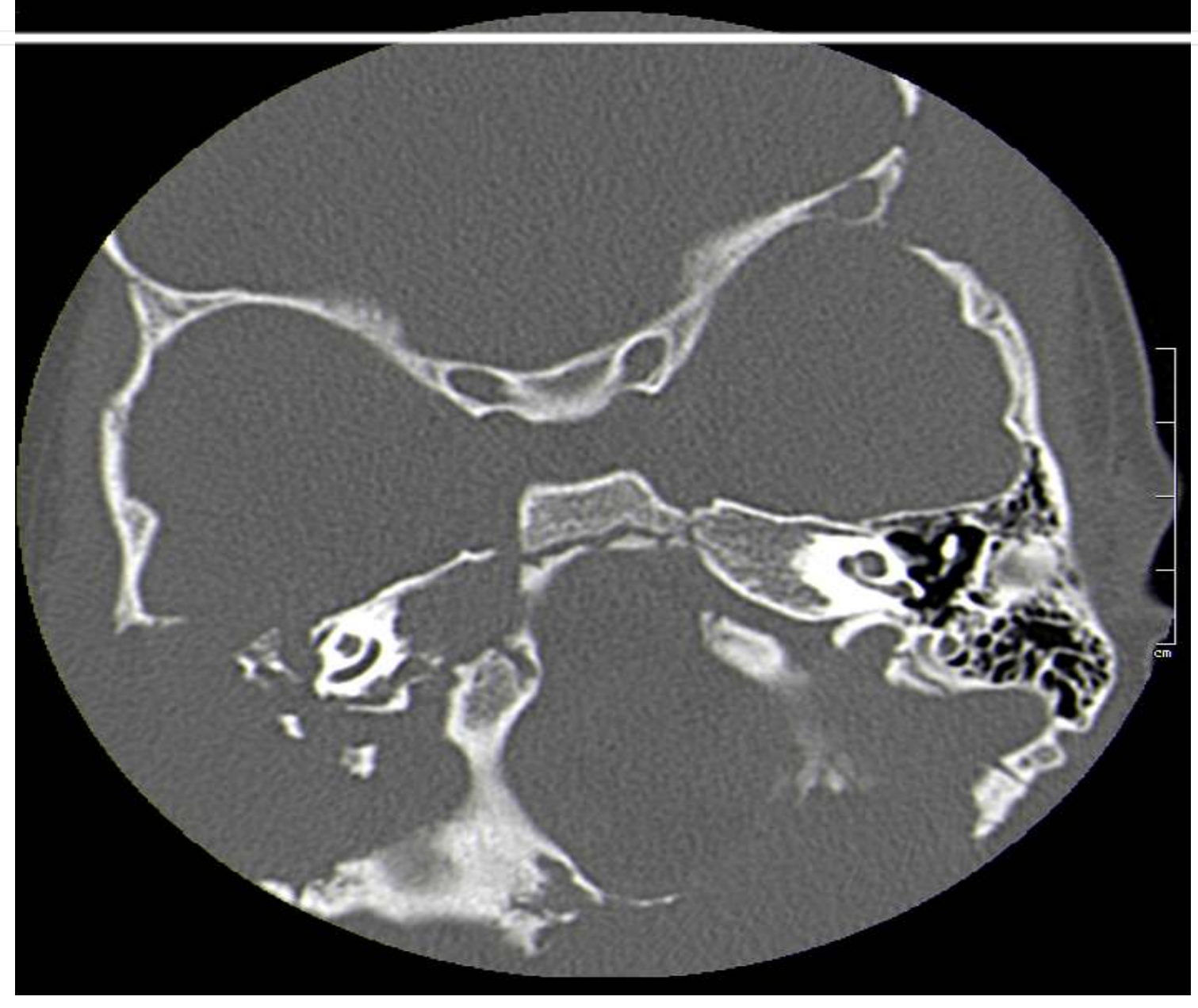

Figure 1. Axial CT temporal bones showing clear destruction of the right temporal bone with loss of mastoid air cells and partial obliteration of petrous apex. $4 \mathrm{~cm} \times 1.9 \mathrm{~cm} \times 6 \mathrm{~cm}$ soft tissue mass was found to be the probable causative finding due to lysis of underlying bone.

\section{LANGERHAN CELL HISTIOCYTOSIS}

- LCH is diagnosed in roughly 50 children in the UK per year.(1) The condition involves the over proliferation of immune "Langerhans Cells" which forms a granulomatous tumour. The disease's classification as a cancer remain dubious and is often under debate.(2)

- LCH usually responds well to treatments given to patients, of which there are a huge range of options available depending on the disease severity, location and number of systems affected.

- These include topical treatments such as steroids and UVA, bisphosphonates, chemotherapy agents, surgical excision. (3)

\section{CASE REPORT}

We present a case of a 3 year-old child seen with chronic unilateral otalgia.

- She underwent an examination under anaesthesia and was initially thought to have congenital cholesteatoma, however Computed Tomography showed osteolytic lesions of the temporal bones with extensive osteolytic destructions involving the bony external auditory canal.

- Magnetic resonance imaging confirmed a soft tissue mass at the occiput with complete lysis of underlying bone.

A radiological diagnosis of $\mathrm{LCH}$ was made, which was later confirmed and managed at a tertiary care centre.

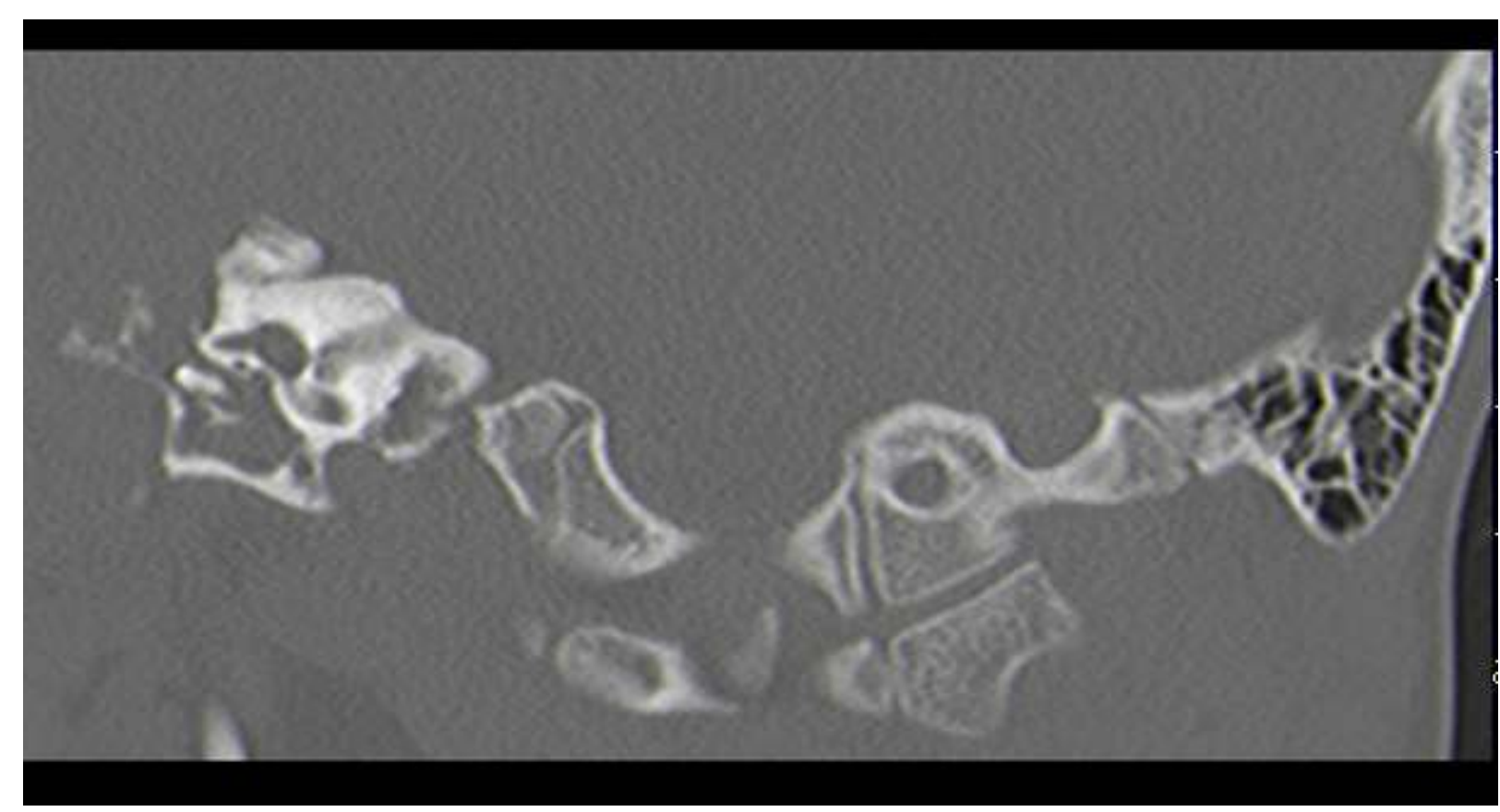

Figure 2. Coronal CT Temporal bones showing loss of mastoid air cells on right side

\section{CONCLUSION}

- $\mathrm{LCH}$ is one of many rare conditions presenting with otalgia or other unexplained ear symptoms.

- Appropriate investigations can aid an early diagnosis in the case of unusual symptomology.

- This case highlights an uncommon disorder with otological involvement, and should be taken into account in paediatric patients presenting with chronic aural symptoms.

\section{References}

1. https://www.macmillan.org.uk/information-and-support/childrenscancer/cancer-types/langerhans-cell-histiocytosis.html

2. https://ghr.nlm.nih.gov/condition/langerhans-cell-histiocytosis\#।

3. https://emedicine.medscape.com/article/1100579-treatment 